九聅虫研会攱 $37: 122-125$ (1991)

Proc. Assoc. Pl. Prot. Kyushu $37: 122-125$ (1991)

\title{
イッポンセスジスズメに対する卵寄生蜂の 寄生率の消長
}

时中章・井上 栄明 - 石丸 知道1.2) - 櫛下町鉦敏 (鹿罗島県農業試験場・1) 鹿児島大学農学部)

\begin{abstract}
Egg parasites of the dasheen horn worm, Theretra pinastrina (MARTYN) (Lepidoptera: Sphingidae): Seasonal prevalence of parasitism in a taro field in Kagoshima Prefecture. Akira TANAKA, Hideaki INOUE, Tomomichi ISHIMARU ${ }^{1)}$ and Kanetosi Kusigemati ${ }^{17}$. (Kagoshima Agriculutural Experiment Station, Kagoshima 891-01. ${ }^{17}$ Faculty of Agriculture, Kagoshima University, Kagoshima 890).
\end{abstract}

サトイモを加害するイッポンセスジスズメ（Theretra pinastrina (MARTYN)) の防除は，8月以降困難であり， 食害の激しい場合は，25～30\%の減収につながる重要害 虫の 1 種である。鹿児島県大隅地方では 8 月以降，本種 の卵に対して畉需生蜂が高率に寄生することが分かって いる(小芦ら，1983）。近年, 害虫の発生機構の中で卵 寄生蜂の役割の重要性が注目されている (平非, 1987)。 本種に奇生する卵奇生蜂の寄生生態を明らかにすること により，天敵の役割を取り入れた生態的防除法を組み立 てる基礎資料とすることができる。ここでは，イッポン セスジスズメに対して1988－1990年に実施した卵寄生蜂 Trichogramma spp. の寄生率消長と若千の生態的知見につ いて調查結果を報告する。

\section{調植地および調查方法}

イッポンセスジスズメの畉消長とその卵笴生蜂の笴生 率の消長調查は，能児岛术上福元町鹿児島婓農業試験場 内で奏施した。1988年と1989年には研究棟の間のビニー ルハウス横に植えた約50株のサトイモ啩，1990年には場 内の周辺にサッマイモ固場のある怔虫部畑ほ場内の 0.9 a のサトイモ戋場で調查した。サトイモ品種は大吉で, 1990年には1部土垂を，4月植付けで，一般慣行栽培法 に準じて栽培した。調榃は，1988年の 9 月6 -30日, 1989年の6月15日〜10月13日，1990年の5月16日〜10月 18日の間奏施した。

調查方法は, 年によって少し晎なるが，週 1ー3 回, 任意の株からイッポンセスジスズメの卵を表垶別に分け て採集し，試験管（径 $10 \mathrm{~mm} \times 90 \mathrm{~mm}) に 1$ 個ずつ入れて室 温下で飼育した。被奇生卵は黒化して八チが羽化するた め, 黒化卵を奇生卵とした。

\footnotetext{
”現在 福网県京都農業改良普及所
}

卵寄生蜂 Trichogramma spp. (以下八千と略記) の発有 零点と有効稹算温度を求めるため，次の予備調查を実施 した。イッポンセスジスズメの室内採卵は困難なため， 野外から笴生を受けていない即を採集することとし，そ のために野外における八千の産卵時刻調查を行った。イ ッポンセスジズズメは夜行性で夜間に産卵するので，採 卵前日に調查区から即を除去しておき，早朝から3時間 おきに訵を採集し，等生の確認を行いハチの産卵開始時 刻を調べた。

ハチの発青零点と有效積算温度は次のようにして求め た。前記のようにして得た野外で産卵した日の未奇生根 を試験管に3個ずつ入れ，その中に辢温で飼育していた 羽化後 4ー5日の八チ10〜20頭を入れ，1～5 時間産卵 させた。産卵された卵は試験管に1個ずつ人れて12本を セットにして，15，20，25，30 $\mathrm{C}$ の温度条件，14明10暗 の日長条件で飼育し，八チの産卵から羽化までの発䏍期 間救めた。

結果

1) 卯等生蜂 Trichogramma spp. の等生率消長

1990年のイッポンセスジスズメの産卵消長と卵奇生蜂 の笴生消長は第 1 表に示す。イッポンセスジスズメの产 畉は全調查期間確認され，5月下旬，8月上旬，9月の 3 回のピークに分けられ，6〜7月にある2回目の制の ピークは明瞭には諗められず，8月から9月へ急速な 増加がみられた。

一方，八チの奇生も5月第 3 週から全調查期間確認さ 扎た。笴生率でみると6月末に 6 月0\%近くまで高くなり， 7 月に20\%と低くなった。その後 7 月の30ー40\%から10 月にかけて高くなり，特に9月に入ってイッポンセスジ スズメの泖が急激に增加したときの笴生率は70一 $85 \%$ に 
第 $\mathrm{l}$ 表 イッポンセスジスズメの産卵消長と Trichugramma spp.の菢生消長（1990）

\begin{tabular}{|c|c|c|c|c|c|c|c|}
\hline \multirow[b]{2}{*}{ 採卵日 } & \multicolumn{5}{|c|}{ イッポンセスジスズメ } & \multicolumn{2}{|c|}{ Trichogramma spp. } \\
\hline & 10株当り產卵数 & 採 卵 数 & 切僻 化 数 & 来卯孚化数 & 米梛化率 & 寄生歌数 & 奇生卵率 \\
\hline 5 月 2 週 & 4.0 & 35 & 34 & 1 & 2.9 & 0 & 0.0 \\
\hline 3 & 5.0 & 86 & 77 & 9 & 10.5 & 7 & 8.1 \\
\hline 4 & 8.3 & 72 & 71 & 1 & 1.4 & 1 & 1.4 \\
\hline 6 月 1 迴 & 2.3 & 30 & 18 & 12 & 40.0 & 10 & 33.3 \\
\hline 2 & 2.7 & 13 & 7 & 6 & 46.2 & 6 & 46.2 \\
\hline 3 & 2.0 & 13 & 4 & 9 & 69.2 & 9 & 69.2 \\
\hline 4 & 1.2 & 7 & 1 & 6 & 85.7 & 6 & 85.7 \\
\hline 7 月 1 週 & 1.4 & 8 & 0 & 8 & 100.0 & 8 & 100.0 \\
\hline 2 & 1.8 & 2] & 15 & 6 & 28.6 & 5 & 23.8 \\
\hline 3 & 2.5 & 27 & 8 & 19 & 70.4 & 19 & 70.4 \\
\hline 4 & 4.3 & 36 & 12 & 24 & 66.7 & 23 & 63.9 \\
\hline 8 月 1 週 & 10.3 & 129 & 83 & 46 & 35.7 & 44 & 34.1 \\
\hline 2 & 13.1 & 184 & 101 & 83 & 45.1 & 75 & 40.8 \\
\hline 3 & 13.6 & 129 & 57 & 72 & 55.8 & 62 & 48.1 \\
\hline 4 & 10.8 & 146 & 22 & 124 & 84.9 & 115 & 78.8 \\
\hline 5 & 7.4 & 107 & 43 & 64 & 59.8 & 64 & 59.8 \\
\hline 9 月 1 速 & 31.6 & 216 & 31 & 185 & 85.6 & 182 & 84.3 \\
\hline 2 & 29.3 & 190 & 42 & 148 & 77.3 & 143 & 75.3 \\
\hline 3 & 29.2 & 164 & 39 & 125 & 76.2 & 119 & 72.6 \\
\hline 4 & 10.6 & 104 & 24 & 80 & 76.9 & 74 & 71.2 \\
\hline 10月 1 週 & 3.5 & 37 & 6 & 31 & 83.8 & 31 & 83.8 \\
\hline 2 & 0.8 & 11 & 1 & 10 & 90.9 & 10 & 90.9 \\
\hline 計, 平均 & & 1765 & 696 & 1073 & 60.8 & 1013 & 57.4 \\
\hline
\end{tabular}

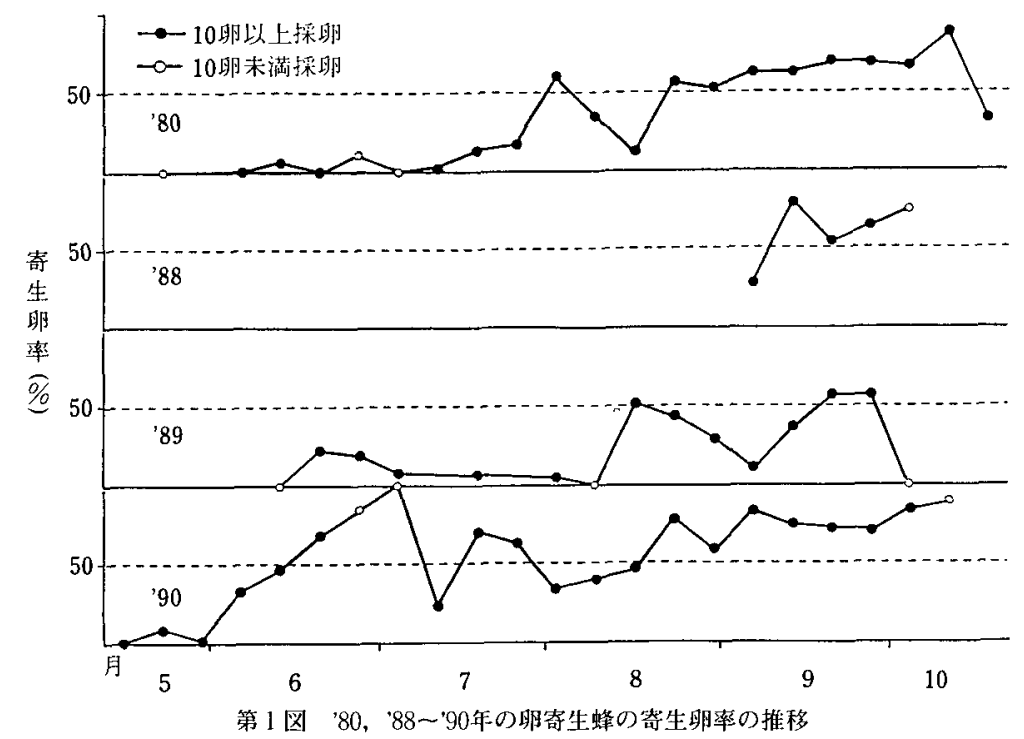

なり，卵が減少してきた10月には90\%以上であった。

1988年と1989年の奇生率の推移は第 1 図に示すように, 1988年においては，9月－10月に25\%から75\%と高かっ たが、1989年には6月〜8月上旬に20\%以下，8月中旬
以降も最高が50\%前後までしか上らず，寄生率は年によ って異なった。

2）サ卜イモの葉の表裏別卵に対する笴生率 1990年の調查では，イッポンセスジスズメの卵は葉表 
第 2 表 イッポンセスジスズメの放数と'88 -90年の葉の 表裹別 Trichogramma spp.の奇生卵率

\begin{tabular}{|c|c|c|c|c|c|}
\hline & 採眀数 & 表採卵数 & 袈採卵数 & 表寄生率 & 襄寄生率 \\
\hline '88年 & 324 & 167 & 157 & 74.3 & 69.4 \\
\hline '89 & 279 & 69 & 210 & 26.1 & 26.7 \\
\hline 90 & 1771 & 637 & 1094 & 67.8 & 53.2 \\
\hline
\end{tabular}

第 3 表 Trichogramma spp. の採卵時刻別寄生率 (1990) 1 回目 $(8 / 14 \sim 8 / 17)$

\begin{tabular}{r|rccc}
\hline 採畉時刻 & 採 卵 数 & 未寄生数 & 寄生数 & 寄生率 \\
\hline $6: 00$ & 23 & 22 & 1 & 4.3 \\
$9: 00$ & 8 & 7 & 1 & 12.5 \\
$12: 00$ & 24 & 11 & 13 & 54.2 \\
$15: 00$ & 30 & 16 & 11 & 36.7 \\
\hline
\end{tabular}

2 回目 $(9 / 7 \sim 9 / 9$ < $9 / 12)$

\begin{tabular}{c|cccc}
\hline \hline 探卵時刻 & 採 卵数 & 未寄生数 & 寄生数 & 寄生率 \\
\hline $6: 00$ & 34 & 33 & 1 & 2.9 \\
$9: 00$ & 23 & 20 & 3 & 13.0 \\
$12: 00$ & 39 & 14 & 25 & 64.1 \\
$15: 00$ & 43 & 13 & 30 & 69.8 \\
\hline
\end{tabular}

第 4 表 Trichogramma spp.の飼育温度別の発育速度（1990）

\begin{tabular}{|c|c|c|c|c|c|}
\hline 温度 & NO & 発青日数 & 発育速度 & 発育零点 & 有効䅡算温度 \\
\hline $15^{\circ} \mathrm{C}$ & 9 & 34.11 & 0.029 & & \\
\hline $20^{\circ} \mathrm{C}$ & 11 & 15.36 & 0.065 & & \\
\hline $25^{\circ} \mathrm{C}$ & 14 & 9.93 & 0.101 & 10.91 & 140.05 \\
\hline $30^{\circ} \mathrm{C}$ & 16 & 7.38 & 0.136 & & \\
\hline
\end{tabular}

以上の結果による1990年の平均気温での 1 世代経過日数

6 月 10.23 日 8 月 7.62 日

7 月 7.78 日 9 月 8.93 日

と葉亭で約 $2 ： 3$ で葉裹に多く産卵され，それぞれの八 fの寄生率は表裏別の全体の寄生率で葉表 $67.8 \%$, 葉裹 53.2\%と表がやや高かった（第 2 表）。

1988年もやや葉表が高く，全体的に奇生率の低かった 1989年もやや葉表の率が高かった。

3) 卵寄生蜂の時刻別寄生率

イッポンセスジスズメの卵を午前 6 時から3 時間每に 採集してハチの奇生率を調べた。2 回の調査結果は第 3

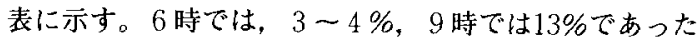
が12時には54〜64\%と急激に高くなった。そして，その 後12〜15時は横ばいかやや高くなる程度であった。この ことから，八千は午前 9 一 12時の間に産畉したことにな る。またここの時期，6時以前には，八チによる産聊は
ほとんよ゙されていないことが分かった。

4) 卵等生蜂の発育零点と有效積算温度

ハチの産卵から羽化まで飼有温度別の発育日数とこれ より求めた発有零点と有効稹算温度は第 4 表に示す。本

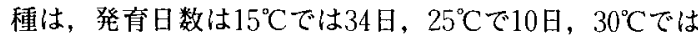
7.4 日と著しく短い日数で発育し, 発育零点は $10.9^{\circ} \mathrm{C}$, 有効積算温度は140.1日度であった。

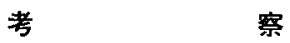

1990年におけるイッポンセスジスズメの産卵消長をみ ると，第 1 表に示すように，産下卵のピークは，5月下 句, 8 月上旬, 9 月上〜中旬に認められた。これらの ピークの間隔から，6月下旬一 7 月上旬にも卵発生の可 能性があるので，この時期の発生を加えると，通常産下 卵のピークは年 4 回みられるのではないかと推察された。 7 月までは密度が低く, 8 月以後の 2 回のピークは著し く高い密度になったが，この傾向は大隅半島における産 膭消長（小芦ら，1983）とほぼ似ていた。しかし，今回 認められた産卵ピークの時期は大隅半島におけるよりも 一旬ぐらい早くなっているようであった。

寄生蜂の奇生率は，小芦らでは7月中旬までは著しく 低率であったのに比べ，1989年では7月まで低率であっ たが，1990年には6月から7月まで高い寄生率で推移し て，その後の奇生率も著しく高くなった。これらの奇生 率の消長を小芦らの消長と比較すると, 調查地点や㡀場 環境が異なるためなのか，年次変動が大きかった。卯笴 生蜂は本種の外に多くの種類の即に寄生するので, 周辺 のほ場環境が八チの発生源となり得るか否かが，イッポ ンセスジスズメの笴生率に影響を与えると考えられる。

葉の表裏別の寄生率は, 葉表がやや高く, 小芦らの報 告と一致した。

八千の時刻別寄生率から，寄生蜂の産卵は早朝 6 時以 前はほとんどみられず，午前 $9 ： 00$ - 12：000間にピー クが来るようであり，今後の奇生率調査の調査時刻等考 虑すべきことになろう。

このハチの発育は著しく早く,これらの有効積算温度 と月平均温度によると 6 月から 9 月の各月の 1 世代経過 日数は第 4 表のようになり，夏季には寄主が 1 世代送る 間，月3〜4回の発生を繰り返すと考えられる。この短 い発有期間と高い性比（小芦ら，1983）により，この八 チは急激な笴生率の高まりを可能としているのであろう。 このハチは Trichogramma sp.であるが, ISHII (1941) に よる検索表では $T$. evanessenseに似ており，小芦らによる 大隅半島のこのハチに関する, 寄生消長, 発育日数など と比較しても同一種が優占種であると思われる。 
摘

\section{要}

サトイモの害虫イッポンセスジスズメの産畉消長とそ の卵寄生蜂の生態について鹿児島市上福元町鹿児島県農 業試験場で1988〜1990年に調査を実施した。

イッポンセスジスズメの産卵は1990年の調查結果では 5 月〜10月まで認められ，その間 8 月と 9 月に大きな增 加がみられた。卵寄生蜂は寄主卵のある全期間奇生が認 められ，寄生率は 6 月末で $100 \%$ 近くまで高くなり， 7 月には20\%と低くなったが，その徯，7月が30４0\%， 9 月が70８5\%，10月が90\%以上と高くなった。奇生率 は年によって異なった。卵は，葉表より葉裏にやや多か ったが，卵寄生蜂の奇生率は葉寒卵よりも葉表卵におい
てやや高かった。

畉寄生蜂は，午前 6 時以前にはほとんど産卵せず，量 間産卵し，産下卵のピークは 9 時〜12時にみられた。卵 寄生蜂の発育零点と有效積算温度は $10.9^{\circ} \mathrm{C}$ と 140.1 日度 であり，6月〜9月には12～16世代を繰り返すことにな る。

\section{引 用 文 献}

1) 平井一男（1987）東北農試研報 $79: 41-64$. 2) ISHII, T. (1941) Kontyu 14: 169-176. 3) 小芦健良・田中章 （1983）鹿児島農試研報 $11 ： 103-117$.

(1991年6月 4 日 受領) 